\title{
Pengaruh Kemampuan Awal terhadap Prestasi Belajar Matematika Siswa
}

\author{
Ihwan Zulkarnain \\ Pendidikan Matematika, Universitas Indraprasta PGRI Jakarta, Indonesia \\ irvan_arie@yahoo.com
}

\begin{abstract}
Abstrak
Tujuan penelitian ini adalah untuk mengetahui dan membuktikan secara empiris Pengaruh Kemampuan Awal Siswa Terhadap Prestasi Belajar Matematika. Metode penelitian yang digunakan adalah metode survei dengan analisis regresi sederhana. Dalam penelitian ini pendekatan yang digunakan adalah pendekatan kuantitatif yang merupakan konsekuensi bahwa seorang peneliti harus bekerja dengan angka-angka sehingga memungkinkan teknik analisa statistik. Penelitian dilaksanakan di SMK Informatika Bina Generasi Kabupaten Bogor tahun ajaran 2018/2019 kelas X dengan jurusan Multimedia. Pengambilan sampel dalam penelitian ini adalah simple random sampling. Tahap yang dilakukan sebanyak 3 stage (tahap), yaitu: tahap pertama memilih kelompok belajar (pada penelitian ini, yang dipilih kelompok belajar reguler), tahap kedua memilih kelas (rombongan belajar), dan tahap ketiga memilih subjek penelitian (siswa). Pengumpulan instrumen yang digunakan untuk pengumpulan data peneliti adalah tes sebanyak 10 soal Uraian untuk kemampuan awal dan 10 soal untuk prestasi belajar matematika. Berdasarkan perhitungan yang telah dilakukan pada taraf signifikan 0,05 , maka diperoleh $F_{\text {hitung }}>F_{\text {tabel }}(4,46>3,00)$ maka $\mathrm{H}_{1}$ diterima yang berarti bahwa terdapat pengaruh yang positif antara kemampuan awal terhadap prestasi belajar matematika.
\end{abstract}

Kata kunci: kemampuan awal, prestasi belajar matematika.

\section{PENDAHULUAN}

Pendidikan merupakan salah satu faktor yang sangat berpengaruh terhadap perkembangan setiap individu untuk mempunyai daya kompetitif, kreatif, dan budi pekerti, yang merupakan kunci utama dalam upaya peningkatan kesejahteraan dan kemakmuran rakyat yang sesuai dengan isi undang-undang dasar 1945 mengamanatkan bahwa pendidikan merupakan hak setiap warga negara. Berdasarkan undang- undang Nomor 20 Tahun 2003 Tentang Sistem Pendidikan Nasional (Depdiknas, 2003), ditegaskan bahwa Pendidikan nasional berfungsi mengembangkan kemampuan dan membentuk watak serta peradaban bangsa yang bermartabat dalam rangka mencerdaskan kehidupan bangsa.

Rendahnya penyediaan sumber daya manusia yang berkualitas saat ini dipengaruhi oleh keadaan yang terjadi di dalam kelas. Pada saat penelitian dilakukan, sering ditemui interaksi guru dan siswa masih belum maksimal, dalam artian guru hanya menjelaskan materi tanpa memperhatikan apakah siswa sudah memahami atau belum. Meskipun begitu guru dan pengajar bukan satu-satunya faktor penentu keberhasilan pendidikan, tetapi pengajaran merupakan titik sentral pendidikan dan kualifikasi, sebagai cermin kualitas, tenaga pengajar memberikan andil sangat besar pada kualitas pendidikan yang menjadi tanggung jawabnya. Berbagai usaha telah dilakukan untuk meningkatkan mutu pendidikan nasional, 
baik dengan pengembangan kurikulum, peningkatan kompetensi guru, pengadaan buku dan sarana prasarana pendidikan. Faktor-faktor inilah yang harus terpenuhi agar pendidikan dapat mencapai tujuannya.

Pemerintah melalui Dinas Pendidikan memegang peranan penting dalam upaya peningkatan mutu pendidikan nasional tersebut. Tojibah \& Suhendri (2015: 28) menyatakan bahwa peningkatan mutu dalam pelayanan meliputi berbagai aspek yakni perencanaan, pelaksanaan, peningkatan, sumber daya manusia, evaluasi, sarana dan prasarana. Peningkatan mutu dalam pelayanan pendidikan yang dilakukan oleh sekolah-sekolah terhadap costumer yang meliputi siswa, orang tua, siswa, maupun masyarakat sekitar harus memiliki berhubungan langsung maupun tidak langsung dengan dunia Pendidikan.

Dalam proses belajar mengajar di sekolah, baik Sekolah Dasar maupun Sekolah Menengah, sering kali ada dijumpai beberapa siswa yang mengalami kesulitan dalam belajar. Aktifitas belajar bagi setiap individu tidak selamanya dapat berlangsung secara wajar. Kadang-kadang lancar, kadang- kadang tidak. Kadangkadang dapat dengan cepat menangkap apa yang dipelajari, kadang-kadang terasa amat sulit. Dalam hal semangat, terkadang semangatnya tinggi, tetapi terkadang juga sulit mengadakan konsentrasi. Karena setiap individu memang tidak ada yang sama. Perbedaan individual inilah yang menyebabkan perbedaan tingkah laku belajar dikalangan anak didik. Dalam keadaan dimana anak didik/siswa tidak dapat belajar sebagaimana mestinya, itulah yang disebut kesulitan belajar (Ahmadi dan Supriyono, 2004: 77).

Beberapa penyebab kesulitan tersebut menurut Supartono (dalam Tojibah \& Suhendri, 2015: 27) antara lain pelajaran matematika tidak tampak kaitannya dalam kehidupan sehari-hari, cara penyajiannya yang monoton dari konsep abstrak menuju konkret, tidak membuat anak senang belajar, sehingga memerlukan pemahaman yang tekun dan teliti. Hal itulah yang membuat banyak siswa menganggap bahwa matematika adalah mata pelajaran yang sulit dan menakutkan, bahkan kebanyakan siswa langsung menyerah jika menghadapi soal matematika. Sehingga mempengaruhi hasil belajar yang dicapai belum memuaskan dan banyak siswa yang masih memperoleh nilai di bawah standar.

Beberapa faktor yang mempengaruhi keberhasilan siswa dalam belajar matematika menurut Astuti (2015: 68) adalah faktor internal yang meliputi kemampuan awal, tingkat kecerdasan, motivasi belajar, kebiasaan belajar, kecemasan belajar, minat belajar, dan sebagainya. Sedangkan faktor eksternal meliputi lingkungan keluarga, lingkungan sekolah, lingkungan masyarakat, keadaan sosial ekonomi, dan sebagainya.

Kemampuan seseorang dalam belajar, mencakup bagaimana sebaiknya belajar dilakukan, apa yang sudah diketahui, dan apa yang belum diketahui serta evaluasi terhadap apa yang direncanakan. Menurut Barbara (dalam Riswanto \& Dasmo 2015: 101), siswa yang memiliki kemampuan awal yang setara bisa menjadi cemerlang atau terpuruk pada suatu mata pelajaran, bergantung pada kecintaan atau kebenciannya pada pelajaran itu. Syah (2004) mengatakan jika kemampuan awal merupakan kemampuan persyaratan terhadap pelajaran berikutnya. Hal ini dibuktikan dengan adanya beberapa siswa yang mampu meraih prestasi belajar matematika cukup baik. Maka dari itu, penting sekali dalam mengetahui latar belakang siswa dalam memahami materi yang dikuasainya agar mempermudah mentransfer ilmu yang akan diberikan dikemudian hari. 
Pada dasarnya, kemampuan awal merupakan kapasitas kognitif yang diperoleh seseorang pada pembelajaran sebelumnya hingga pada proses pembelajaran yang baru. Menurut Astuti (2015: 74), kemampuan awal seseorang siswa dalam proses belajar mengajar sangat diperlukan terutama untuk membekali siswa dalam mempelajari materi yang lebih tinggi. siswa yang memiliki kemampuan awal yang lebih tinggi akan mudah mengerti dan memahami materi pelajaran yang disampaikan oleh guru dan memungkinkan akan mendapatkan prestasi belajar yang lebih baik.

Kemampuan menggunakan pengetahuan dan konsep belajar matematika merupakan dasar dalam peningkatan prestasi belajar siswa. Guru berperan penting dalam proses belajar di sekolah sehingga tujuan pembelajaran dapat tercapai. Setelah siswa melakukan kegiatan belajar maka mereka akan memperoleh apa yang disebut prestasi belajar. Prestasi digunakan sebagai tolok ukur kriteria dalam mencapai suatu tujuan pendidikan. Menurut Sudjana (dalam Nurrahmah, 2015: 108), Prestasi belajar adalah tingkat penguasaan siswa yang mencakup ranak kognitif, afektif dan psikomotorik. Jadi bukti bahwa seseorang telah belajar ialah terjadinya perubahan tingkah laku pada orang tersebut, misalnya dari tidak tahu menjadi tahu, dari yang tidak mengerti menjadi mengerti.

Untuk menilai Prestasi belajar yang telah dicapai oleh siswa dalam proses belajar mengajar, perlu dilakukan suatu kegiatan evaluasi. Evaluasi dalam proses belajar mengajar merupakan bagian yang sangat penting. Bahkan, dapat dipandang sebagai bagian yang tak terpisahkan dari proses belajar mengajar tersebut telah berhasil atau belum. Maka seluruh hasil yang dicapai melalui proses belajar mengajar dinyatakan berdasarkan hasil tes belajar dan evaluasi guna melihat perkembangan kemampuan siswa.

Ada beberapa faktor yang mempengaruhi prestasi belajar siswa, yaitu faktor internal dan faktor eksternal. Menurut Slameto (dalam Susilawati \& Budi, 2015: 82), faktor internal adalah faktor yang ada di dalam individu yang sedang belajar, sedangkan faktor eksternal adalah faktor yang ada di luar individu. Faktor internal meliputi intelegensi, motivasi, kebiasaan, kecemasan, minat, dan sebgainya, sedangkan faktor eksternal meliputi lingkungan keluarga, lingkungan sekolah, lingkungan masyarakat, keadaan sosial, ekonomi, dan sebagainya.

Melihat kenyataan tersebut, dapat dijelaskan bahwa rendahnya prestasi belajar matematika siswa dapat diatasi dengan menemukan akar permasalahan yang tepat. Dari kondisi yang muncul diduga adanya pengaruh langsung antara kemampuan awal siswa terhadap prestasi belajar. Semakin tinggi kualitas kemampuan awal akan semakin baik pula prestasi belajar siswa. Penelitian ini dimaksudkan untuk menguji kebenaran hipotesis penelitian dengan judul Pengaruh kemampuan awal matematika terhadap prestasi belajar matematika.

\section{METODE PENELITIAN}

Penelitian yang digunakan adalah penelitian dengan metode survei dengan analisis regresi sederhana. Dalam penelitian ini pendekatan yang digunakan adalah pendekatan kuantitatif yang merupakan konsekuensi bahwa seorang peneliti harus bekerja dengan angka-angka sehingga memungkinkan teknik analisa statistik. Dalam penelitian survei, peneliti tidak melakukan perubahan terhadap variabelvariabel tertentu, sehingga peneliti meneliti sesuai dengan keadaan sebenarnya. 
Dalam hal ini, peneliti memperoleh data kemampuan awal dan prestasi belajar matematika dengan menggunakan instrumen test uraian sebanyak 10 soal dengan materi logika matematika.

Penelitian dilakukan di SMK Informatika Bina Generasi Kabupaten Bogor dengan total siswa 641. Populasi pada penelitian ini adalah peserta didik kelas $X$ dengan total jumlahnya 204 siswa, dan terdaftar pada tahun ajaran 2018/2019 semester genap. Sampel yang akan diambil adalah kelas XA dan XB sebanyak 67 peserta didik. Teknik sampling dalam penelitian ini adalah simple random sampling. Adapun teknik analisis data berupa teknik analisis deskriptif yang meliputi Penyajian distribusi data dan Pengolahan data. Sedangkan teknik pengujian Persyaratan data meliputi uji normalitas, uji linearitas regresi, Uji korelasi, Analisis Regresi, dan Hipotesis Statistik.

\section{HASIL DAN PEMBAHASAN}

Pada penelitian ini populasi berasal dari kelas X multimedia SMK Informatika Bina Generasi Kabupaten Bogor Tahun Pelajaran 2018/2019 semester genap sebagai sampel sebanyak 67 siswa yang terdiri dari 35 orang siswa lai-laki dan 32 orang siswa perempuan. Dari sampel sebanyak 67 siswa tersebut diperoleh nilai atau skor Kemampuan awal dan prestasi belajar matematika siswa melalui tes pada materi logika matematika. Berikut ini akan disajikan data hasil penelitian berupa hasil perhitungan akhir.

Dari hasil tes tertulis soal matematika pada materi logika matematika yang menggunakan instrumen tes berbentuk uraian sebanyak 10 butir pada sampel yaitu siswa kelas XA dan XB multimedia diperoleh data kemampuan awal dan prestasi belajar matematika sebagai berikut:

Tabel 1. Distribusi frekuensi prestasi belajar

\begin{tabular}{ccccccccrr}
\hline No. & \multicolumn{2}{l}{ Interval kelas } & fo & $\mathrm{F}$ & $\mathrm{Xi}$ & fo.Xi & $(\mathrm{Xi}-\mathrm{X})^{2}$ & fo. $(\mathrm{Xi}-\mathrm{X})^{2}$ \\
\hline 1 & 45 & - & 51 & 3 & 3 & 48 & 144 & 490,6 & 1471,8 \\
2 & 52 & - & 58 & 3 & 6 & 55 & 165 & 229,5 & 688,5 \\
3 & 59 & - & 65 & 15 & 21 & 62 & 930 & 66,4 & 996,2 \\
4 & 66 & - & 72 & 21 & 42 & 69 & 1449 & 1,3 & 27,7 \\
5 & 73 & - & 79 & 13 & 55 & 76 & 988 & 34,2 & 445,0 \\
6 & 80 & - & 86 & 8 & 63 & 83 & 664 & 165,1 & 1321,1 \\
7 & 87 & - & 95 & 4 & 67 & 90 & 360 & 394,1 & 1576,2 \\
\hline$\sum$ & \multicolumn{1}{c}{67} & & & 4700 & & 6526,5 \\
\hline
\end{tabular}

Tabel 2. Distribusi frekuensi Kemampuan Awal Siswa

\begin{tabular}{|c|c|c|c|c|c|c|c|c|}
\hline No & \multicolumn{2}{|c|}{ Interval kelas } & fo & $\mathrm{F}$ & $\mathrm{Xi}$ & fo.Xi & $(\mathrm{Xi}-\mathrm{X}) 2$ & fo. $(\mathrm{Xi}-\mathrm{X}) 2$ \\
\hline 1 & 33,3 & $-41,3$ & 2 & 2 & 37,3 & 74,6 & 1022,1 & 2044,2 \\
\hline 2 & 42,3 & $\begin{array}{l}-\quad 50,3 \\
\end{array}$ & 8 & 10 & 46,3 & 370,4 & 527,6 & 4221,0 \\
\hline 3 & 51,3 & $\begin{array}{l}-\quad 59,3 \\
\end{array}$ & 6 & 16 & 55,3 & 331,8 & 195,2 & 1171,0 \\
\hline 4 & 60,3 & - $\quad 68,3$ & 12 & 28 & 64,3 & 771,6 & 24,7 & 296,4 \\
\hline 5 & 69,3 & - $\quad 77,3$ & 19 & 47 & 73,3 & 1392,7 & 16,2 & 308,6 \\
\hline 6 & 78,3 & $-\quad 86,3$ & 14 & 61 & 82,3 & 1152,2 & 169,8 & 2376,9 \\
\hline 7 & 87,3 & $-\quad 95,3$ & 6 & 67 & 91,3 & 547,8 & 485,3 & 2911,9 \\
\hline$\sum$ & & & 67 & & & 4641,1 & & 13329,9 \\
\hline
\end{tabular}


Tabel 3. Perbandingan Analisis deskripsi data

\begin{tabular}{lccccc}
\hline Variable & $\begin{array}{c}\text { Mean } \\
(\bar{X})\end{array}$ & $\begin{array}{c}\text { Median } \\
\left(M_{e}\right)\end{array}$ & $\begin{array}{c}\text { Modus } \\
\left(M_{o}\right)\end{array}$ & $\begin{array}{c}\text { Varians } \\
\left(S^{2}\right)\end{array}$ & $\begin{array}{c}\text { Simpangan } \\
\text { Baku }(s)\end{array}$ \\
\hline Prestasi Belajar & 70,1 & 69,7 & 65,93 & 98,87 & 9,94 \\
\hline Kemampuan awal & 69,3 & 71,41 & 74,02 & 201,97 & 14,21 \\
\hline
\end{tabular}

Uji normalitas diberikan kepada kedua variabel penelitian dan diharapkan data yang diperoleh dari hasil penelitian berdistribusi normal. Untuk menguji kenormalan hasil penelitian digunakan uji normalitas Chi-Kuadrat pada taraf $\alpha=5 \%$ atau sama dengan 0,05 dan disajikan dalam bentuk tabel berikut ini.

Tabel 4. Perhitungan Uji Normalitas Prestasi Belajar Matematika

\begin{tabular}{|c|c|c|c|c|c|c|c|c|c|c|c|}
\hline \multirow[t]{2}{*}{ No. } & \multicolumn{3}{|c|}{$\begin{array}{c}\text { Interval } \\
\text { kelas }\end{array}$} & \multirow[t]{2}{*}{ fo } & \multirow{2}{*}{$\begin{array}{r}\text { Tepi } \\
\text { kelas } \\
44,5\end{array}$} & \multirow{2}{*}{$\begin{array}{c}\mathrm{Z} \\
\text { score } \\
-2,58\end{array}$} & \multirow{2}{*}{$\begin{array}{c}\begin{array}{c}\text { nilai z } \\
\text { tabel }\end{array} \\
0,4951\end{array}$} & F(zi) & \multirow[t]{2}{*}{$\mathrm{Li}$} & \multirow[t]{2}{*}{ fe } & \multirow[t]{2}{*}{$\begin{array}{l}\text { (fo- } \\
\text { fe) } 2 / \mathrm{fe}\end{array}$} \\
\hline & & & & & & & & 0,0049 & & & \\
\hline 1 & 45 & - & 51 & 3 & & & & & 0,0252 & 1,688 & 1,019 \\
\hline & & & & & 51,5 & $-1,88$ & 0,4699 & 0,0301 & & & \\
\hline 2 & 52 & - & 58 & 3 & & & & & 0,0909 & 6,090 & 1,568 \\
\hline & & & & & 58,5 & $-1,17$ & 0,379 & 0,121 & & & \\
\hline 3 & 59 & 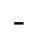 & 65 & 15 & & & & & 0,1982 & 13,279 & 0,223 \\
\hline 4 & 66 & - & 72 & 21 & 65,5 & $-0,47$ & 0,1808 & 0,3192 & 0,2756 & 18,465 & 0,348 \\
\hline 5 & 73 & - & 79 & 13 & 72,5 & 0,24 & 0,0948 & 0,5948 & 0,2316 & 15,517 & 0,408 \\
\hline 6 & 80 & - & 86 & 8 & 79,5 & 0,94 & 0,3264 & 0,8264 & 0,1231 & 8,248 & 0,007 \\
\hline 7 & 87 & - & 95 & 4 & 86,5 & 1,64 & 0,4495 & 0,9495 & 0,0451 & 3,022 & 0,317 \\
\hline$\sum$ & & & & 67 & 95,5 & 2,55 & 0,4946 & 0,9946 & & $X_{2}=$ & 3,890 \\
\hline
\end{tabular}

Dari hasil perhitungan dalam tabel tersebut, didapat hasil nilai $X_{2}=3,890$, sedangkan dari tabel Chi Kuadrat untuk $\alpha=0,05$ dan $\mathrm{dk}=6$ didapat nilai $\mathrm{X}_{\text {tabel }}=$ 12,592 Karena nilai $X_{\text {hitung }} 3,890<X_{\text {tabel }} 12,592$ maka $H_{0}$ diterima dan dapat disimpulkan bahwa data Prestasi belajar Siswa berasal dari populasi berdistribusi normal.

Tabel 5. Perhitungan Uji Normalitas Kemampuan Awal

\begin{tabular}{|c|c|c|c|c|c|c|c|c|c|c|}
\hline No. & Inter & al kelas & fo & $\begin{array}{c}\text { tepi } \\
\text { kelas }\end{array}$ & $\begin{array}{c}\mathrm{z} \\
\text { score }\end{array}$ & $\begin{array}{c}\text { nilai z } \\
\text { tabel }\end{array}$ & $\mathrm{F}(\mathrm{zi})$ & $\mathrm{Li}$ & fe & $\begin{array}{c}\text { (fo- } \\
\text { fe) } 2 / \mathrm{fe}\end{array}$ \\
\hline \multirow{3}{*}{1} & \multirow{3}{*}{33,3} & \multirow{3}{*}{41,3} & \multirow{3}{*}{2} & 32,8 & $-2,57$ & 0,494 & 0,005 & \multirow{3}{*}{0,019} & \multirow{3}{*}{1,333} & \multirow{3}{*}{0,333} \\
\hline & & & & & & & & & & \\
\hline & & & & 41,4 & $-1,96$ & 0,475 & 0,025 & & & \\
\hline \multirow[t]{2}{*}{2} & \multirow[t]{2}{*}{42,3} & \multirow[t]{2}{*}{50,3} & \multirow[t]{2}{*}{8} & & & & & \multirow[t]{2}{*}{0,071} & \multirow[t]{2}{*}{4,811} & \multirow[t]{2}{*}{2,115} \\
\hline & & & & 50,8 & $-1,30$ & 0,403 & 0,096 & & & \\
\hline \multirow[t]{2}{*}{3} & \multirow[t]{2}{*}{51,3} & \multirow[t]{2}{*}{ - $\quad 59,3$} & \multirow[t]{2}{*}{6} & & & & & \multirow[t]{2}{*}{0,145} & \multirow[t]{2}{*}{9,728} & \multirow[t]{2}{*}{1,429} \\
\hline & & & & 59,4 & $-0,70$ & 0,258 & 0,242 & & & \\
\hline
\end{tabular}


93|Zulkarnain, Pengaruh Kemampuan Awal Terhadap ...

\begin{tabular}{|c|c|c|c|c|c|c|c|c|c|c|c|}
\hline \multirow[t]{2}{*}{4} & 60,3 & - & 68,3 & 12 & & & & & 0,246 & 16,482 & 1,219 \\
\hline & & & & & 68,8 & $-0,03$ & 0,012 & 0,488 & & & \\
\hline \multirow[t]{2}{*}{5} & 69,3 & - & 77,3 & 19 & & & & & 0,237 & 15,933 & 0,591 \\
\hline & & & & & 77,8 & 0,60 & 0,225 & 0,725 & & & \\
\hline \multirow[t]{2}{*}{6} & 78,3 & - & 86,3 & 14 & & & & & 0,165 & 11,048 & 0,789 \\
\hline & & & & & 86,8 & 1,23 & 0,390 & 0,890 & & & \\
\hline \multirow[t]{2}{*}{7} & 87,3 & - & 95,3 & 6 & & & & & 0,078 & 5,266 & 0,102 \\
\hline & & & & & 95,8 & 1,87 & 0,469 & 0,969 & & & \\
\hline$\sum$ & & & & 67 & & & & & & $X_{2}=$ & 6,577 \\
\hline
\end{tabular}

Dari hasil perhitungan dalam tabel tersebut, didapat hasil nilai $X_{2}=6,577$ sedangkan dari tabel Chi Kuadrat untuk $\alpha=0,05$ dan $\mathrm{dk}=6$ didapat nilai $\mathrm{X}_{\text {tabel }}=$ 12,592 Karena nilai $\mathrm{X}_{\text {hitung }} 6,577<\mathrm{X}_{\text {tabel }} 12,592$ maka $\mathrm{H}_{0}$ diterima dan dapat disimpulkan bahwa data Prestasi belajar Siswa berasal dari populasi berdistribusi normal.

Tabel 6. Penolong ANOVA Kelinearan Regresi

\begin{tabular}{lccccc}
\hline Sumber Varians & Dk & JK & RJK & $F_{\text {hitung }}$ & $F_{\text {tabel }}$ \\
\hline Total & 67 & 344925 & - & & \\
Regresi (a) & 1 & 337463,06 & 337463,06 & & \\
Regresi (b/a) & 1 & 478,79 & 478,79 & & \\
Residu & 65 & 6983,15 & 107,43 & 4,46 & 3,00 \\
Tuna Cocok & 12 & $-2786056,06$ & $-232171,3$ & & \\
Kesalahan (error) & 53 & 2793039,21 & 52698,85 & & \\
\hline
\end{tabular}

Berdasarkan perhitungan diatas, didapat $\mathrm{F}_{\text {hitung }}=4,46$ dan $\mathrm{F}_{\text {tabel }}=3,00$, sehingga $F_{\text {hitung }}>F_{\text {tabel, }}$ karena $F_{\text {hitung }}>F_{\text {tabel }}, \mathrm{H}_{1}$ diterima dan $\mathrm{H} 0$ ditolak. maka dapat disimpulkan bahwa adanya pengaruh yang signifikan antara kemampuan awal tehadap prestasi belajar matematika.

Berdasarkan penelitian yang telah dilakukan, maka diperoleh $F_{\text {hitung }}=4,46$, jika dikonsultasikan dengan $F_{\text {tabel }}$ pada taraf signifikan 0,05 dengan $\mathrm{dk}(1)=3,00$, dengan demikian karena $F_{\text {hitung }}>F_{\text {tabel }}(4,46>3,00)$ maka $\mathrm{H} 1$ diterima yang berarti bahwa terdapat pengaruh yang positif antara kemampuan awal terhadap prestasi belajar matematika. Hal ini sependapat dengan hasil peneliti Muzayyin (2010) yang menyatakan bahwa terdapat pengaruh yang signifikan antara kemampuan awal terhadap prestasi belajar matematika. Melalui penelitiannya, terlihat adanya pengaruh antara kemampuan awal siswa terhadap prestasi belajar matematika sebesar 0,25 , angka ini dapat diartikan sebagai hubungan yang cukup positif dengan kontribusi yang diberikan oleh variabel kemampuan awal siswa terhadap prestasi belajar matematika yaitu $6,25 \%$, yang artinya $6,25 \%$ prestasi belajar matematika dipengaruhi oleh faktor kemampuan awal siswa, dan sisanya dipengaruhi oleh faktor lain yang tidak dibahas pada penelitian ini. Hal ini pun menguatkan penelitian yang dilakukan oleh Prihatin (2014), bahwa terdapat pengaruh yang signifikan antara kemampuan awal terhadap prestasi belajar matematika.

Dari perhitungan yang diperoleh diatas dapat disimpulkan bahwa dengan kemampuan awal yang dimiliki oleh siswa sebelum memulai pelajaran baru, dan 
akan lebih memudahkan dalam memahami pelajaran yang akan dipelajari, serta selanjutnya akan memberi pengaruh yang positif pada prestasi belajar matematika.

\section{KESIMPULAN}

Simpulan yang dapat diambil adalah dari hasil pengolahan data secara kuantitatif yang diperoleh melalui survei dan pengujian hipotesis yang telah dilaksanakan di SMK Informatika Bina Generasi, maka didapatkan hasil penelitian bahwa terdapat pengaruh yang signifikan antara kemampuan awal terhadap prestasi belajar matematika. Sedangkan saran untuk guru yaitu penelitian diharapkan dapat mengurangi sistem belajar yang menyamaratakan kemampuan siswa, agar siswa mampu mempelajari materi baru dengan kemampuan awal yang sudah ia miliki sebagai upaya meningkatkan kualitas pembelajaran matematika. Bagi siswa, penelitian ini diharapkan dapat memberikan pemahaman bahwa disetiap jenjang pendidikan saling berkaitan dan mempengaruhi satu sama lain.

\section{REFERENSI}

Ahmadi, A., \& Supriyono, W. (2004). Psikologi Belajar. Jakarta: PT. Rineka Cipta. Astuti, P. S. (2015). Pengaruh Kemampuan Awal dan Minat Belajar terhadap Prestasi Belajar Fisika. Formatif: Jurnal Ilmiah Pendidikan MIPA, 5(1), 68-75.

Depdiknas. (2003). Undang-undang Nomor 20 tentang Sistem Pendidikan Nasional. Jakarta: Depdiknas.

Muzayyin. (2010). Pengaruh Kemampuan Awal dan Minat Belajar Siswa terhadap Prestasi Belajar Matematika. Skripsi: Universitas Indraprasta PGRI.

Nurrahmah, A. (2015). Pengaruh Kecerdasan Logik Matematika dan Minat Belajar terhadap Prestasi Belajar Matematika. Formatif,: Jurnal Ilmiah Pendidikan MIPA, 5(2), 107-199.

Prihatin. (2014). Pengaruh Kemampuan Awal terhadap Prestasi Belajar Matematika. Skripsi: Universitas Indraprasta PGRI Jakarta.

Riswanto, H. \& Dasmo. (2015). Upaya Meningkatkan Hasil Belajar Ilmu Pengetahuan Alam (IPA) dengan Metode Pembelajaran Mind Map. Formatif: Jurnal Ilmiah Pendidikan MIPA, 5(2), 100-106.

Slameto. (2010). Belajar dan Faktor-Faktor yang Mempengaruhinya. Jakarta: Rineka Cipta.

Susilawati, \& Budi. (2015). Pengaruh Kemampuan Metakognitif Peserta Didik terhadap Prestasi Belajar Matematika. Jakarta: Edu Research, Unindra Press.

Syah, M. (2004). Psikologi Pendidikan dengan Pendekatan Baru. Bandung: Remaja Rosdakarya.

Tojibah, \& Suhendri. (2015). Efektifitas Penerapan Strategi Pembelajaran Metakognitif dalam Pembelajaran Matematika. Jakarta: Edu Research, Unindra Press. 